\title{
Relationship between Fusarium Head Blight, Kernel Damage, Concentration of Fusarium Biomass, and Fusarium Toxins in Grain of Winter Wheat Inoculated with Fusarium culmorum
}

\author{
Tomasz Góral ${ }^{1, * \mathbb{C}}$, Halina Wiśniewska ${ }^{2}$, Piotr Ochodzki ${ }^{1}$, Linda Kærgaard Nielsen ${ }^{3}$, \\ Dorota Walentyn-Góral ${ }^{1}$ and Łukasz Stępień ${ }^{2}$ D \\ 1 Department of Plant Pathology, Plant Breeding and Acclimatization Institute-National Research Institute, \\ Radzików, 05-870 Błonie, Poland; p.ochodzki@ihar.edu.pl (P.O.); d.walentyn-goral@ihar.edu.pl (D.W.-G.) \\ 2 Institute of Plant Genetics, Polish Academy of Sciences, Strzeszyńska 34, 60-479 Poznań, Poland; \\ hwis@igr.poznan.pl (H.W.); lste@igr.poznan.pl (Ł.S.) \\ 3 Sejet Plant Breeding, Nørremarksvej 67, 8700 Horsens, Denmark; 1kn@sejet.dk \\ * Correspondence: t.goral@ihar.edu.pl; Tel.: +48-22-733-4636
}

Received: 31 October 2018; Accepted: 19 December 2018; Published: 21 December 2018

\begin{abstract}
Winter wheat lines were evaluated for their reaction to Fusarium head blight (FHB) after inoculation with Fusarium culmorum in two field experiments. A mixture of two F. culmorum chemotypes was applied (3ADON-deoxynivalenol producing, NIV-nivalenol producing). Different types of resistance were evaluated, including head infection, kernel damage, Fusarium biomass content and trichothecenes B (deoxynivalenol (DON), and nivalenol (NIV)) accumulation in grain. The aim of the study was to find relationships between different types of resistance. Head infection (FHB index) and Fusarium damaged kernels (FDK) were visually scored. Fusarium biomass was analysed using real-time PCR. Trichothecenes B accumulation was analysed using gas chromatography. Wheat lines differ in their reaction to inoculation for all parameters describing FHB resistance. We found a wide variability of FHB indexes, FDK, and Fusarium biomass content. Both toxins were present. DON content was about $60 \%$ higher than NIV and variability of this proportion between lines was observed. Significant correlation was found between head infection symptoms and FDK. Head infection was correlated with F. culmorum biomass and NIV concentration in grain. No correlation was found between the FHB index and DON concentration. Similarly, FDK was not correlated with DON content, but it was with NIV content; however, the coefficients were higher than for the FHB index. Fusarium biomass amount was positively correlated with both toxins as well as with the FHB index and FDK. Environmental conditions significantly influenced the DON/NIV ratio in grain. In locations where less F. culmorum biomass was detected, the DON amount was higher than NIV, while in locations where more F. culmorum biomass was observed, NIV prevailed over DON.
\end{abstract}

Keywords: Fusarium DNA; Fusarium head blight; deoxynivalenol; nivalenol; real time PCR; resistance

Key Contribution: Relationship between the amount of F. culmorum biomass and trichothecene toxins (DON, NIV) is stronger than the relationship between visual FHB index and toxin amount. Different patterns of DON and NIV production were observed when related to FHB severity, as measured with the FHB index, FDK, and F. culmorum biomass.

\section{Introduction}

Fusarium head blight (FHB) is a cereal disease caused by fungi of the Fusarium genus. These fungi infect cereal heads, causing necrosis of spikelets, kernel infection and damage, and contamination of 
tissues and grain with Fusarium toxins [1]. Fusarium species produce many toxins of different chemical groups. As a small grain cereals contaminants, the most important are trichothecenes (primarily deoxynivalenol $=\mathrm{DON}$, nivalenol $=\mathrm{NIV}, \mathrm{T}-2 / \mathrm{HT}-2$ toxins), zearalenone, and moniliformin [2] Resistance to Fusarium head blight is a composite, quantitative trait. Several types (mechanisms) of resistance were identified [3,4]. They were described as: Type I-resistance to initial infection, type II-to Fusarium spread in the spike [5]; type III—to kernel damage, type IV—tolerance against FHB or trichothecene toxins [6]; type V-resistance to accumulation of trichothecene toxins subdivided into: Class 1-by chemical modification [7]; class 2-by hindering of trichothecene synthesis [8].

Resistance levels of type I and type II affect the severity of head infection under field conditions. A high level of type I resistance is relevant in the case of strong pressure of Fusarium infection [9]. On the other side, low resistance type II may result in severe head infection despite low infection pressure [10].

It is difficult to estimate resistance type I due to effects of other traits that affect its proper measurement. This trait is the type of flowering [11-13]. For wheat and triticale, three types of flowering were described: Open (chazmogamic), when all three anthers escape out of the flower; (cleistogamic), when all the anthers remain inside the flower; and mixed flowering, when one or two anthers remain inside of the flower [14]. As demonstrated in published studies, the least infected were cleistogamic genotypes, whereas the most infected were genotypes of mixed-type flowering [15]. Such observations can be associated with the influence of the presence of anthers containing substances (choline, glycine betaine) stimulating the growth of Fusarium [16-19]. Another factor that may cause difficulties in accurate evaluation is the spread of Fusarium to the adjacent spikelets. Based on research available $[16,20]$, about $5-7$ days after infection, the pathogen reaches the rachis and grows up or down the head. Consequently, the assessment of the type I resistance requires appropriate methodology. Spraying the heads with spore suspension and observing the number of infected spikelets approximately one week after inoculation is the most commonly used technique [21]. Heads should be inoculated in the same developmental stage (at full anthesis). Occasionally, trichothecene non-producing isolates are also applied, due to their low ability to spread in the head [22].

Precise evaluation of resistance to Fusarium spread (type II) is much simpler [23]. Therefore, this type of resistance is most often used in genetic studies on determination of quantitative traits loci (QTL) [24-26]. The experimental protocol for the resistance type II is, however, quite labour-intensive because it consists of point inoculation of individual heads [27-29]. This is done mainly by injecting the spore suspension to the flower in the middle spikelet of the head. Less commonly, cotton balls soaked in a suspension or fine infested kernels are used (e.g., millet) $[25,27,30,31]$. The development of the disease is assessed by determining the number of flowers/spikelets with symptoms of necrosis or bleaching. Scoring should be carried out once about 21 days after inoculation, or several times after inoculation in order to accurately determine the rate of the disease progress [10]. It was found that the maximum genetic diversity in terms of resistance occurs about 3 weeks after inoculation with use of DON $[25,32]$. In susceptible genotypes, the spikelets above the infection point may be dead (wilting), which is a reaction to the phytotoxic effect of DON [33,34].

Assessment of resistance type III determines the proportion of kernels damaged by Fusarium in grain sample. This is determined by dividing the sample into factions: Kernels with signs of damage by Fusarium (shrivelled, discoloured-white, pink, orange, carmine) and healthy-looking kernels [9]. The percentage of kernels with Fusarium damage in the sample is calculated. This type of resistance can also be assessed by analysing the content of ergosterol in the grain. Ergosterol is a component of the cell membranes of fungi [35]. Its contents indicate the amount of mycelium in the grain, which indirectly determines the degree of infection by the Fusarium fungi. The amount of mycelium in kernels can also be specified by measuring Fusarium DNA content in grain using quantitative PCR (real-time PCR) [36-40]. This method is more accurate because it specifically detects Fusarium fungi (or selected Fusarium species) in the grain [41-43]. Ergosterol specifies the amount of the whole mycobiota, also of fungi outside of Fusarium genus [44]. 
Type IV resistance (tolerance) is determined by measuring the reduction of grain yield caused by Fusarium head blight, followed by a comparison of the degree of kernel damage and concentration of Fusarium toxins in the grain [3]. Tolerance to Fusarium head blight (precisely: Tolerance to Fusarium head blight or trichothecenes) occurs when the reduction of yield is low despite a strong infection of heads/kernel damage/accumulation of toxins in the grain. Concerning Fusarium head blight, tolerance is not a favorable trait [4]. High tolerance may result in a high yield of seemingly lightly damaged grain that may be contaminated with Fusarium toxins.

The type V resistance is evaluated by quantifying the content of Fusarium toxins in the grain [8]. Different methods are applied, such as immunoenzymatic tests or the more precise chromatographic techniques (gas chromatography, liquid chromatography), including the usage of advanced detectors, such as mass spectrometers. In the study of resistance involving chemical modification of the toxins, the amount of 'masked mycotoxins' is also determined [45]. These are toxins undergoing glycosylation, which results in the formation of compounds non-toxic to plants, e.g., DON-3-glucoside and zearalenone 14-glucoside. In research on resistance involving blocking the synthesis of toxins, it is important to determine the content of compounds with antioxidant activity, such as phenolic compounds, phenolic acids, carotenoids, or peptides [46].

In this study, we evaluated the reaction of winter wheat breeding lines to Fusarium head blight. Plants were inoculated with F. culmorum isolates in field trials. We scored the characters describing different types of resistance, including head infection (types I and II), kernel damage (type III), Fusarium biomass concentration in kernels (type III), and trichothecenes group B (DON, DON acetyl derivatives, NIV) accumulation in grain (type V). Results were analysed to find relationships between different characters. As we used mixed inoculation with two chemotypes of F. culmorum (3ADON and NIV), we studied the proportions of both toxins in the grain in two experimental environments as well as the relationships between FHB visual assessment parameters and toxin contents.

\section{Results}

Winter wheat lines were inoculated with F. culmorum isolates in two field trials. Head infection was scored as the FHB index. After the harvest, the proportion of Fusarium damaged kernels (FDK) was assessed. Grain was analysed for the concentration of F. culmorum DNA expressing the amount of F. culmorum biomass. Finally, the concentration of Fusarium toxins belonging to group B of trichothecenes were analysed.

The average FHB index amounted to $11.1 \%$ in wheat grown in Cerekwica, ranging from $2.0 \%$ to $41.4 \%$. In wheat grown in Radzików, the FHB index was $25.7 \%$, ranging from $9.3 \%$ to $48.0 \%$. The overall FHB index for the two locations was $18.4 \%$ (Table 1). The average FDK for grain from Cerekwica was $15.2 \%$, ranging from $3.9 \%$ to $29.9 \%$. The FDK for grain from Radzików was more than 2 -fold higher and amounted to $38.9 \%$, at a range of $10.1-86.5 \%$. The overall FDK proportion for the two locations was $27.0 \%$ (Table 1 ).

Fusarium culmorum biomass was detected in all grain samples. The average concentration for Cerekwica was $22.2 \mathrm{pg}$ of F. culmorum DNA per one ng of wheat DNA. It ranged from 2.1 to $66.7 \mathrm{pg} / \mathrm{ng}$. The average from Radzików was 2-fold higher and amounted to $45.8 \mathrm{pg} / \mathrm{ng}$ with a range from 10.1 to $134.4 \mathrm{pg} / \mathrm{ng}$. It directly corresponds to a much higher FDK in Radzików. Overall, the Fusarium biomass concentration for the two locations was $34.0 \mathrm{pg} / \mathrm{ng}$ (Table 1 ).

Presence of DON, 3AcDON (3-acetyl-DON), and NIV was confirmed in all wheat grain samples. Amount of $3 A c D O N$ was low with the average at $0.081 \mathrm{mg} / \mathrm{kg}(0.008-0.297 \mathrm{mg} / \mathrm{kg})$. It was about $2.8 \%$ of the average DON amount. DON and 3AcDON amounts correlated highly significantly $(r=0.913)$ so they were further shown as the total amount of DON and 3AcDON. No 15-acetyl-DON was detected.

The average amount of DON (+3AcDON) in grain in Radzików was $1.390 \mathrm{mg} / \mathrm{kg}$ and it was 3 -fold lower than in Cerekwica $(4.418 \mathrm{mg} / \mathrm{kg})$. Similarly, the variation range was wider in Cerekwica $(0.100-14.427 \mathrm{mg} / \mathrm{kg})$ than in Radzików $(0.282-3.103 \mathrm{mg} / \mathrm{kg})$. Average NIV concentration was $2.578 \mathrm{mg} / \mathrm{kg}$ in Radzików, with a range of $0.336-8.820 \mathrm{mg} / \mathrm{kg}$, and 3-fold higher than in Cerekwica 
$(0.982 \mathrm{mg} / \mathrm{kg}$, with a range of $0.044-3.318 \mathrm{mg} / \mathrm{kg})$. Overall, the amount of DON + 3AcDON for the two locations was $2.904 \mathrm{mg} / \mathrm{kg}$ (Table 1 ).

To summarize, concentrations of trichothecenes B (DON + 3AcDON + NIV) in wheat grain in both localities were similar-5.401 mg/kg in Cerekwica and $3.968 \mathrm{mg} / \mathrm{kg}$ in Radzików. However, a higher amount of F. culmorum biomass found in grain in Radzików led to a higher biomass/trichothecenes ratio in this environment (12.6), compared to Cerekwica (5.6). Regarding the individual toxins, the biomass/DON ratio was low in Cerekwica (8.0) and high in Radzików (34.0). The biomass/NIV ratio was lower in Radzików (22.4) than in Cerekwica (37.1). The overall amount of trichothecenes B for the two locations was $4.684 \mathrm{mg} / \mathrm{kg}$ (Table 1 ).

Table 1. Fusarium head blight resistance of 27 winter wheat lines inoculated with $F$. culmorum isolates in two locations-Radzików and Cerekwica.

\begin{tabular}{|c|c|c|c|c|c|c|c|c|}
\hline No. & Line $^{1}$ & $\begin{array}{c}\text { Fusarium } \\
\text { Head Blight } \\
\text { Index }(\%)\end{array}$ & $\begin{array}{c}\text { Fusarium } \\
\text { Damaged } \\
\text { Kernels (\%) }\end{array}$ & $\begin{array}{c}\text { F.c. } \\
\text { Biomass } \\
\text { (pg/ng) }\end{array}$ & $\begin{array}{l}\text { DON }^{2} \\
(\mathrm{mg} / \mathrm{kg})\end{array}$ & $\begin{array}{c}\text { NIV } \\
(\mathrm{mg} / \mathrm{kg})\end{array}$ & $\begin{array}{c}\text { TRT }^{3} \\
(\mathrm{mg} / \mathrm{kg})\end{array}$ & $\begin{array}{c}\text { Biomass/TRT } \\
\text { Ratio }\end{array}$ \\
\hline 2 & MHR 2 & 6.9 & 9.4 & 7.3 & 1.057 & 0.482 & 1.539 & 4.7 \\
\hline 3 & STH 1 & 24.1 & 24.0 & 21.4 & 0.608 & 1.001 & 1.609 & 13.3 \\
\hline 4 & SMH 2 & 12.9 & 22.0 & 34.1 & 0.576 & 1.198 & 1.774 & 19.2 \\
\hline 6 & DANKO 4 & 18.1 & 15.8 & 37.0 & 1.532 & 0.702 & 2.234 & 16.6 \\
\hline 7 & MHR 1 & 11.1 & 24.1 & 25.9 & 1.428 & 0.939 & 2.367 & 10.9 \\
\hline 8 & SMH 3 & 15.4 & 22.6 & 24.6 & 0.870 & 1.533 & 2.403 & 10.2 \\
\hline 9 & STH 5 & 17.5 & 13.0 & 19.7 & 1.805 & 1.007 & 2.812 & 7.0 \\
\hline 10 & PHR 2 & 17.8 & 15.4 & 23.0 & 2.100 & 1.148 & 3.248 & 7.1 \\
\hline 11 & SMH 1 & 17.2 & 24.4 & 21.3 & 1.911 & 1.557 & 3.468 & 6.1 \\
\hline 15 & Tonacja cv. & 12.3 & 27.8 & 25.3 & 2.717 & 1.515 & 4.232 & 6.0 \\
\hline 16 & PHR 3 & 13.2 & 26.3 & 24.5 & 3.005 & 1.667 & 4.672 & 7.7 \\
\hline 17 & PHR 1 & 12.5 & 34.6 & 29.9 & 2.286 & 2.573 & 4.859 & 6.1 \\
\hline 18 & MHR 3 & 23.5 & 30.3 & 33.8 & 3.096 & 1.795 & 4.891 & 6.9 \\
\hline 19 & MHR 4 & 17.6 & 15.6 & 27.3 & 4.173 & 1.249 & 5.422 & 5.0 \\
\hline 20 & DANKO 2 & 9.5 & 22.5 & 37.1 & 4.304 & 1.602 & 5.906 & 6.3 \\
\hline 21 & DANKO 3 & 19.0 & 32.9 & 50.8 & 3.068 & 3.064 & 6.132 & 8.3 \\
\hline 22 & STH 3 & 28.8 & 45.1 & 87.8 & 3.804 & 3.253 & 7.057 & 12.4 \\
\hline 23 & STH 2 & 44.7 & 52.8 & 67.6 & 3.262 & 4.110 & 7.372 & 9.2 \\
\hline 24 & PHR 4 & 16.0 & 18.0 & 33.5 & 6.005 & 1.540 & 7.545 & 4.4 \\
\hline 25 & STH 4 & 24.6 & 57.8 & 66.6 & 5.811 & 3.612 & 9.423 & 7.1 \\
\hline
\end{tabular}

\footnotetext{
${ }^{1}$ Lines sorted according to total concentration of trichothecenes $\mathrm{B} ;{ }^{2}$ total amount of DON and $3 \mathrm{AcDON}$;

${ }^{3} \mathrm{TRT}=$ trichothecenes, sum of DON, 3AcDON, and NIV.
}

The wheat lines differed in their reaction to F. culmorum inoculation for all parameters describing FHB resistance (Table 1). The most resistant to head infection and kernel damage was line MHR 2. This line also showed the lowest FDK and amount of F. culmorum biomass in the grain. Line MHR 2 also displayed high resistance in terms of trichothecenes concentration. However some lines accumulated lower amounts of DON (MHR 5, STH 1, SMH 2) or NIV (MHR 5, STH 8), despite higher Fusarium infection. This resulted in a low biomass/trichothecenes ratio (4.7) for MHR 2 compared with other low toxin contaminated lines, e.g., MHR 5 (26.8), STH 1 (13.3), or SMH 2 (19.2).

The highest head infection was seen in line STH 2 (Table 1). This line also had a high FDK proportion. However, some lines of lower infected heads had similar FDK-STH 4 (57.8\%) and DANKO $1(50.1 \%)$.

K-means analysis grouped lines based on their FHB resistances of different types (Figure 1, Table 2). 


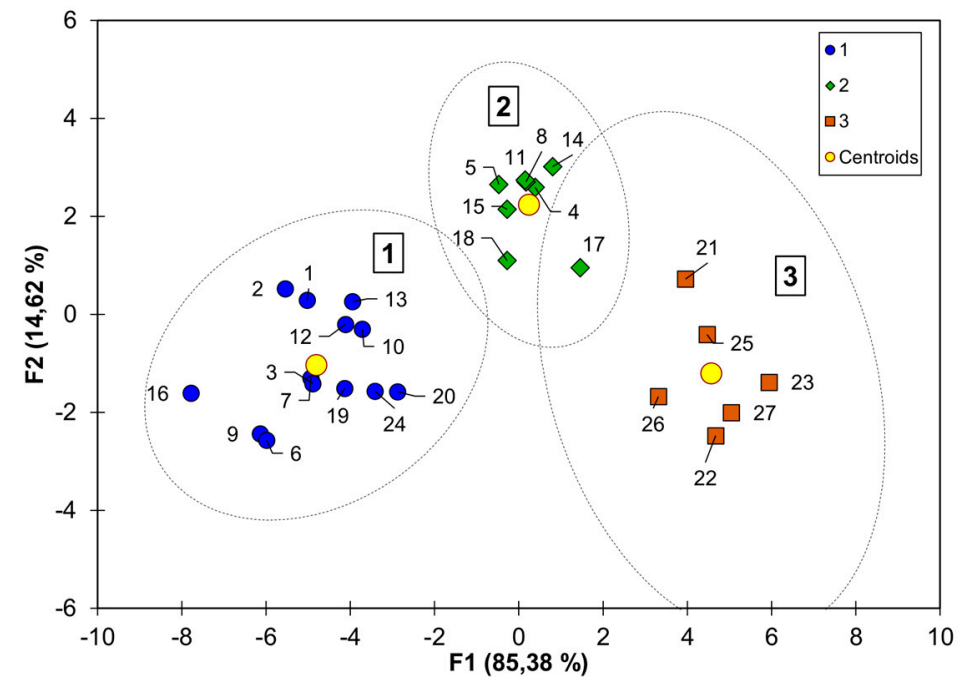

Figure 1. Canonical discriminant analysis of Fusarium head blight index, Fusarium damaged kernels, and concentrations of biomass of Fusarium culmorum and mycotoxins-DON (+3AcDON) and NIV in grain of 26 winter wheat lines and cultivar 'Tonacja'. Classes $(1,2,3)$ defined by k-means analysis. Line numbers correspond to those in Table 1.

Table 2. Average values and ranges for classes created by k-means cluster analysis of FHB index, FDK, F. culmorum biomass, and DON and NIV concentrations in grain of 27 wheat lines.

\begin{tabular}{|c|c|c|c|c|c|c|c|}
\hline Class & $\begin{array}{l}\text { No. of } \\
\text { Lines }\end{array}$ & $\begin{array}{c}\text { FHBi } \\
(\%)\end{array}$ & $\begin{array}{c}\text { FDK } \\
(\%)\end{array}$ & $\begin{array}{l}\text { F.c. Biomass } \\
\text { (pg/ng) }\end{array}$ & $\begin{array}{l}\text { DON }^{1} \\
(\mathrm{mg} / \mathrm{kg})\end{array}$ & $\begin{array}{c}\mathrm{NIV} \\
(\mathrm{mg} / \mathrm{kg})\end{array}$ & $\begin{array}{l}\text { Biomass/TRT } \\
{ }^{2} \text { Ratio }\end{array}$ \\
\hline 1 & 13 & $\begin{array}{c}15.2 \\
(6.9-24.1)\end{array}$ & $\begin{array}{c}17.5 \\
(9.4-26.7)\end{array}$ & $\begin{array}{c}23.4 \\
(7.3-37.1)\end{array}$ & $\begin{array}{c}2.330 \\
(0.371-6.005)\end{array}$ & $\begin{array}{c}0.944 \\
(0.335-1.602)\end{array}$ & $\begin{array}{c}9.3 \\
(4.4-26.8)\end{array}$ \\
\hline 2 & 8 & $\begin{array}{c}16.2 \\
(12.3-23.5)\end{array}$ & $\begin{array}{c}27.7 \\
(22.0-34.6)\end{array}$ & $\begin{array}{c}28.8 \\
(21.3-36.6)\end{array}$ & $\begin{array}{c}2.142 \\
(0.576-3.096)\end{array}$ & $\begin{array}{c}1.653 \\
(1.198-2.573)\end{array}$ & $\begin{array}{c}8.6 \\
(5.3-19.2)\end{array}$ \\
\hline 3 & 6 & $\begin{array}{c}28.3 \\
(19.0-44.7)\end{array}$ & $\begin{array}{c}46.9 \\
(32.9-57.8)\end{array}$ & $\begin{array}{c}66.5 \\
(50.7-87.8)\end{array}$ & $\begin{array}{c}5.165 \\
(3.068-8.303)\end{array}$ & $\begin{array}{c}3.762 \\
(3.064-4.998)\end{array}$ & $\begin{array}{c}7.7 \\
(4.5-12.4)\end{array}$ \\
\hline Total/mean & 27 & 18.4 & 27.0 & 34.0 & 2.904 & 1.780 & 8.7 \\
\hline
\end{tabular}

The biomass/trichothecenes ratio was the lowest in the group of susceptible lines (class 3); it was, however, not very different from the ratios for the other groups (Table 2).

The majority of lines showed biomass/trichothecenes ratio values between 5 and 10 (Figure 2). However, five lines with higher values were identified. Four of them accumulated low amounts of trichothecenes B (STH 1, DANKO 4, SMH 2, MHR 5) while one line (STH 3) accumulated more trichothecenes and contained the highest concentration of F. culmorum biomass in grain. 
Scatter plot(Biomass/TRT ratio vs Trich)

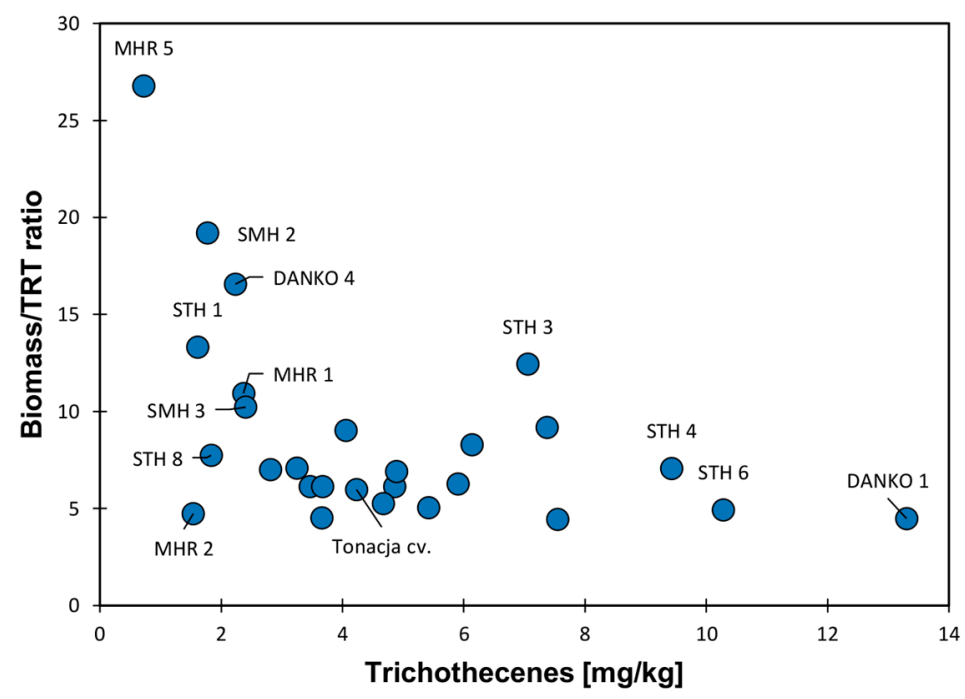

Figure 2. Relationship between concentration of trichothecenes ( $D O N+3 A c D O N+N I V)$ in grain and the F. culmorum biomass/trichothecenes (TRT) ratio for 27 winter wheat lines.

A significant linear relationship was found between head infection (FHBi) and amount of Fusarium damaged kernels (Table 3). Head infection was also positively correlated with F. culmorum biomass and NIV concentration in grain. No significant correlation was found between FHBi and DON concentration. A proportion of Fusarium damaged kernels correlated well with F. culmorum biomass and NIV concentration. The coefficient for FDK vs. DON was insignificant. The F. culmorum biomass amount correlated significantly with the concentration of both mycotoxins; however, the value of the coefficient for DON was much lower than for NIV. The biomass/trichothecenes ratio correlated positively with head infection, kernel damage, and F. culmorum biomass. The correlation coefficient ratio vs. DON was significant and negative, whereas there was no correlation with NIV.

Table 3. Correlations between FHB index (FHBi), FDK, F. culmorum biomass (F.c. biomass), concentration of DON, NIV, and sum of trichothecenes in grain (TRT), and the ratio of fungal biomass per amount of DON + NIV produced (Biomass/TRT) for data for 27 winter wheat lines from two locations (54 samples). Variables log transformed.

\begin{tabular}{ccccccc}
\hline Variables $(\boldsymbol{n}=\mathbf{5 4 )}$ & $\begin{array}{c}\text { FHBi } \\
(\mathbf{\%})\end{array}$ & $\begin{array}{c}\text { FDK } \\
(\mathbf{\%})\end{array}$ & $\begin{array}{c}\text { F.c. Biomass } \\
(\mathbf{p g} / \mathbf{n g})\end{array}$ & $\begin{array}{c}\text { DON } \\
(\mathbf{m g} / \mathbf{k g})\end{array}$ & $\begin{array}{c}\text { NIV } \\
(\mathbf{m g} / \mathbf{k g})\end{array}$ & $\begin{array}{c}\text { TRT } \\
(\mathbf{m g} / \mathbf{k g})\end{array}$ \\
\hline FDK [\%] & $\mathbf{0 . 7 8 0}$ & & & & & \\
F.c. biomass [pg/ng) & $\mathbf{0 . 6 4 8}$ & $\mathbf{0 . 7 9 2}$ & & & & \\
DON [mg/kg) & -0.173 & 0.102 & $\mathbf{0 . 3 1 9}$ & & & \\
NIV [mg/kg) & $\mathbf{0 . 6 7 2}$ & $\mathbf{0 . 8 0 2}$ & $\mathbf{0 . 8 0 1}$ & $\mathbf{0 . 2 9 1}$ & & \\
TRT [mg/kg) & 0.191 & $\mathbf{0 . 5 0 9}$ & $\mathbf{0 . 6 4 9}$ & $\mathbf{0 . 8 5 8}$ & $\mathbf{0 . 7 0 4}$ & \\
Biomass/TRT ratio & $\mathbf{0 . 5 4 5}$ & $\mathbf{0 . 3 3 9}$ & $\mathbf{0 . 4 2 1}$ & $\mathbf{- 0 . 6 4 1}$ & 0.117 & $\mathbf{0 . 4 1 8}$ \\
\hline
\end{tabular}

${ }^{1}$ Total amount of DON and 3AcDON; values displayed in bold are significant at the 0.05 significance level.

As the differences in the relationship of DON and NIV versus FHB resistance traits (FHBi, FDK, F.c. biomass) were observed, data from the two trials were analysed separately. A significant correlation was found between the FHBi and DON concentration in Radzików, but not in Cerekwica (Table 4). Coefficients of correlations for FHBi vs. F. culmorum biomass and NIV were twice as high in Radzików than in Cerekwica. Regarding the FDK, correlations with DON and NIV in both environments were significant. However, the coefficient of correlation for FDK vs. DON was higher in Cerekwica, while the coefficient of correlation for FDK vs. NIV was higher in Radzików than in Cerekwica. The same was true for the F. culmorum biomass. 
Table 4. Correlations between FHB index (FHBi), FDK, F. culmorum biomass (F.c. biomass), and concentration of DON and NIV in grain of 27 winter wheat lines in Cerekwica (C) and Radzików (R). Variables $\log$ transformed.

\begin{tabular}{|c|c|c|c|c|c|c|c|c|c|}
\hline Variables & $\begin{array}{c}\text { FHBi } \\
\text { C }\end{array}$ & $\begin{array}{c}\text { FHBi } \\
\text { R }\end{array}$ & $\begin{array}{c}\text { FDK } \\
\text { C }\end{array}$ & $\begin{array}{c}\text { FDK } \\
\mathbf{R}\end{array}$ & $\begin{array}{c}\text { F.c. } \\
\text { Biomass C }\end{array}$ & $\begin{array}{c}\text { F.c. } \\
\text { Biomass } \mathrm{R}\end{array}$ & $\begin{array}{c}\text { DON }^{1} \\
\text { C }\end{array}$ & $\begin{array}{c}\text { DON }^{1} \\
\text { R }\end{array}$ & $\begin{array}{c}\text { NIV } \\
\text { C }\end{array}$ \\
\hline FHBi R & 0.464 & & & & & & & & \\
\hline FDK C & 0.578 & 0.610 & & & & & & & \\
\hline FDK R & 0.146 & 0.670 & 0.491 & & & & & & \\
\hline F.c. biomass $\mathrm{C}$ & 0.381 & 0.388 & 0.672 & 0.285 & & & & & \\
\hline F.c. biomass $\mathrm{R}$ & 0.259 & 0.744 & 0.559 & 0.796 & 0.254 & & & & \\
\hline $\mathrm{DON}^{1} \mathrm{C}$ & 0.212 & 0.243 & 0.663 & 0.185 & 0.748 & 0.174 & & & \\
\hline $\mathrm{DON}^{1} \mathrm{R}$ & 0.102 & 0.514 & 0.523 & 0.462 & 0.374 & 0.580 & 0.482 & & \\
\hline NIV C & 0.428 & 0.268 & 0.589 & 0.208 & 0.692 & 0.194 & 0.750 & 0.509 & \\
\hline NIV R & 0.125 & 0.711 & 0.484 & 0.899 & 0.328 & 0.813 & 0.383 & 0.540 & 0.280 \\
\hline
\end{tabular}

${ }^{1}$ Total amount of DON and 3AcDON; values displayed in bold are significant at the 0.05 significance level.

To explain the differences between DON and NIV relations with other resistance traits, we analysed the linear regression between them. Figure 3 present the linear regression of FDK and F. culmorum biomass versus DON concentration and NIV concentration in two experimental environments. The DON concentration in grain in Cerekwica was higher than in Radzików for the majority of the samples despite the FDK or amount of F. culmorum biomass (Figure 3A,B). The NIV concentration increased with the increase of FDK or F. culmorum biomass in grain (Figure 3C,D). However, it was noticeable that in Cerekwica, some lines with similar FDK values accumulated different amounts of NIV. It was less expressed for F. culmorum biomass.
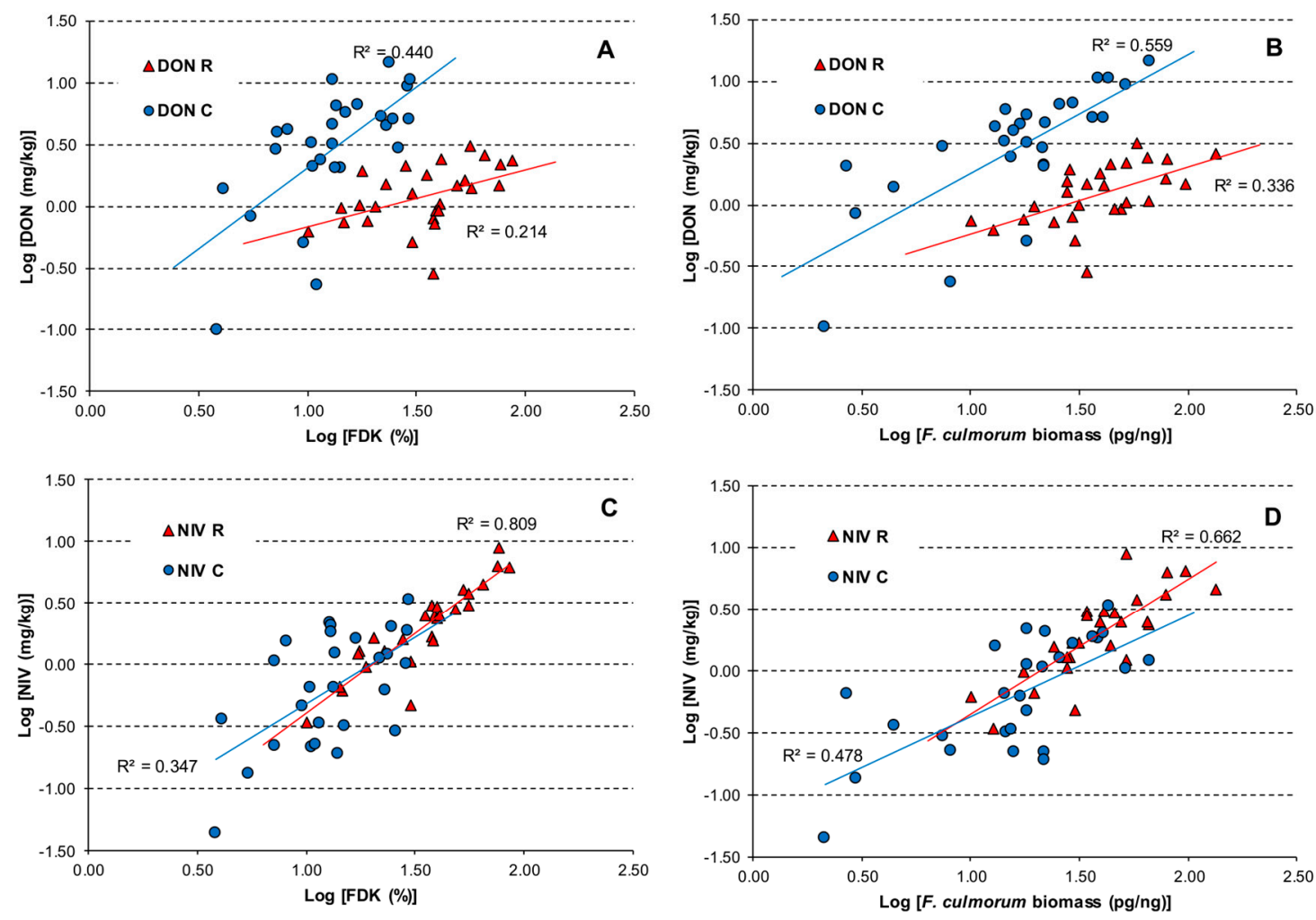

Figure 3. Relationships between FDK and concentration of DON (+3AcDON) (A) and NIV (C) and the amount of F. culmorum biomass and concentration of DON (+3AcDON) (B) and NIV (D) in grain of wheat lines in Cerekwica (C) and Radzików (R). 
Hence, the low correlation of the DON amount with phenotypic characters (FHBi, FDK) and F. culmorum biomass and high values of coefficients for NIV (Table 3).

\section{Discussion}

In both locations, inoculations were effective even though weather conditions during flowering were unfavourable for Fusarium infection. In Cerekwica, the influence of drought conditions was compensated by application of mist irrigation post inoculation. In Radzików, evening inoculations were sufficient for infection. However, weather conditions in the following weeks were unfavourable for the appearance of FHB symptoms in Cerekwica, which resulted in differences in FHB indexes, FDK values, and DON content. Higher FDK values in Radzików can be explained by the incidence of low and frequent rainfalls in Radzików in July. In comparison, Cerekwica was affected by drought in July, slowing down the development of FHB. The concentration of DON in grain was relatively low, even though the proportion of Fusarium damaged kernels was high. On the contrary, NIV concentration was high, mostly in Radzików. The amount of NIV in wheat grain samples in Radzików was 2-fold higher than the DON amount.

The results show that the environmental conditions significantly influenced the ratio of the $3 \mathrm{ADON} /$ NIV chemotype and affected the shift between DON/NIV production. It appears that in Radzików, conditions were more favourable for NIV chemotype development. The F. culmorum NIV chemotype outcompeted the DON chemotype in Radzików, and in Cerekwica, the situation was the opposite. We can presume that we are dealing with competition between two chemotypes of the same species competition between the two chemotypes of the same species. Van der Ohe and Miedaner [47] described the competition between F. culmorum and F. graminearum species. They also included one isolate of $F$. graminearum NIV chemotype. This isolate showed similar pathogenicity to other DON chemotype isolates. Mixture of DON+NIV chemotypes had stable pathogenicity (FHB rating), but differed in toxin production across environments. The concentration of NIV after mixture inoculations was not determined, hence the concentration in the first experimental year is unknown. The results showed that the NIV chemotype isolate dominated this year.

Only the total Fusarium biomass was analysed, so the ratio of 3ADON/NIV chemotypes biomass in single grain samples is unknown. This issue could be resolved by quantitative analysis of 3ADON and NIV chemotypes biomass of F. culmorum [48]. The NIV chemotype is generally considered less aggressive than DON (3ADON, 15ADON) chemotypes [49,50]. However, our results showed that it could produce considerable amounts of NIV even in mixture with a more aggressive isolate of the 3ADON chemotype. This is evident in lines, PHR 1, DANKO 3, and STH 3, in which amounts of DON and NIV were similar, and line STH 2, which accumulated more NIV than DON in grain (Table 1).

Linear relationships of F. culmorum biomass vs. NIV were significant in both locations. This was probably, as mentioned above, the result of different mycotoxin (DON vs. NIV) profiles in the two locations. These differences are shown in the figures. Figure 3D shows a clear effect of the increasing amount of F. culmorum biomass on NIV content. Figure 3B shows a weak linear effect of the increasing amount of F. culmorum biomass on DON content for all samples. However, linear relationships were highly significant in the two locations separately. NIV content in grain was low in Cerekwica, which was in accordance with the lower amount of F. culmorum biomass than that observed in Radzików. It seems that the DON/NIV ratio depended strongly on environmental conditions. As in Cerekwica, conditions after inoculations were drier than in Radzików; we can presume that they were favourable for a more aggressive $3 \mathrm{ADON}$ chemotype. Whether or not it was caused by competition of two F. culmorum isolates of different chemotypes is unknown and the issue needs further research. The DON vs. NIV relationship was significant, but weak for data from both locations differing in environmental conditions. However, it was highly significant to separate data from locations. DON and NIV are both FHB aggressiveness factors and cause similar symptoms on wheat heads [51]. Despite this fact, differences in the detoxification mechanism of both toxins were found. Lemmens et al. [40] suggested that different genes in the Fhb1 gene cluster may be involved in resistance to these toxins. NIV is less 
toxic to wheat plants than DON and NIV isolates appear to be less aggressive [52,53]. On the contrary, NIV is more toxic to humans and animals [54]. Amounts of NIV detected in agricultural products are lower than amounts of DON, but both mycotoxins can co-occur and pose a threat to consumers when their total amount is above maximum limits [55].

Comparing the correlation coefficients between different parameters of FHB assessment (FHBi, FDK, F. culmorum biomass) and toxin content, we find that biomass is the best predictor of the amount of trichothecene toxins. The FHB index correlated with DON and NIV in Radzików, but not with DON in the different environment in Cerekwica and only weakly with NIV. It resulted in a lack of correlation with DON and the sum of trichothecenes. Higher and significant coefficients were observed for FDK in separate samples from locations; however, for aggregated samples, the coefficient for DON was insignificant. Mesterhazy [3] showed such variability of relationships in multi-year experiments.

Brunner et al. [56] studied relationships between visual scoring, infection determined with real-time PCR, and toxin (DON + D3G) content in grain for wheat inoculated with F. graminearum and F. culmorum. They found that evaluation of FHB resistance based on DNA quantification is more reliable than on visual scoring, especially for lines that are more resistant. They observed low compliance of visual scoring with toxins and DNA for F. graminearum, but high for F. culmorum. We observed the same for results from Radzików, where FHB severity and toxin content was high, but not for Cerekwica, where FHB infection was much lower. Horevaj et al. [57] obtained similar results for F. graminearum. Visual assessment of FHB severity showed lower correlations with DON content than FDK and F. graminearum biomass. They tested FHB resistant lines and susceptible check and observed very low FHB severity for resistant lines and high for check. Whereas, for FDK and biomass, the resistant were evenly distributed and some lines showed values close to the susceptible check.

A stronger relationship between Fusarium biomass and DON content than between the FHB index, FDK, or other visual scoring parameters has been confirmed by other authors [37,58-60]. Rossi et al. [60] studied FHB resistance parameters in bread wheat and durum wheat inoculated with F. culmorum and F. graminearum. They found stable relationships between Fusarium biomass and DON content for different species of wheat and Fusarium in different environments.

The above results confirm that selection for FHB resistance based only on visual scoring does not necessarily ensure low levels of trichothecenes in grain of selected lines. It is less problematic in wheat, where in most cases, the severity of symptoms of head infection significantly correlates with toxin content (in experimental conditions) [61,62]. However, in triticale, a weak relationship between head infection and toxin content in grain is frequently observed, and in many cases, between the severity of kernel damage and toxins [63-67].

\section{Conclusions}

Environmental conditions significantly influenced the DON/NIV ratio in grain when wheat heads were inoculated with a mixture of two chemotypes of F. culmorum-3ADON and NIV. In the location where lower F. culmorum biomass was detected, the amount of DON was higher than NIV. While in the location where F. culmorum biomass concentration was higher, NIV prevailed over DON.

The relationship between Fusarium biomass and trichothecenes B content in grain was stronger than between visually scored head infection (FHB index) and the proportion of damaged kernels (FDK). We found differences in the relationship between Fusarium biomass vs. DON or NIV. For NIV, increasing the amount of Fusarium biomass in grain from both locations resulted in an increase in the amount of NIV. Whereas for DON, the same amounts of Fusarium biomass in two locations resulted in different amounts of DON. 


\section{Materials and Methods}

\subsection{Fusarium culmorum Isolates}

Inoculum for field experiments was produced from three Fusarium culmorum isolates. Two of them (KF846, ZFR112) were 3ADON chemotypes and one (KF350) was the NIV-chemotype. These produced DON and 3AcDON-KF846, ZFR112 as well as NIV-KF350 [68]. Isolates of 3ADON chemotype were isolated originally from wheat heads collected in Radzików, Poland $[68,69]$. The isolate, KF350 (NIV chemotype), was isolated from wheat heads collected in the Netherlands [70].

Species identity of the strains was confirmed using species-specific molecular markers [71,72]. Moreover, a portion of fungal TEF-1 $\alpha$ gene was amplified, sequenced, and analysed, as described previously [73]. Gene-specific markers were used to identify TRI5, TRI13, and PKS13 genes, characteristic for trichothecene and zearalenone chemotypes of Fusarium spp. Sequencing of the amplified DNA fragments was conducted to confirm the chemotypes of the strains. All primer sequences, PCR amplification, and sequencing protocols were described in a previous work [73].

Fusarium culmorum isolates were incubated on autoclaved wheat grain in $300 \mathrm{~mL}$ Erlenmeyer glass flasks for 7 days in darkness at $18{ }^{\circ} \mathrm{C}$, and next exposed to near ultraviolet light $(350 \mathrm{~nm})$ with a 16-h photoperiod at $15^{\circ} \mathrm{C}$ for about 21 days. Flasks were shaken thoroughly every day to prevent sticking of the grain overgrown with the mycelium. Grain with visible sporulation of F. culmorum on the kernel surface was dried and stored in at $4{ }^{\circ} \mathrm{C}$ until use. Prior to the inoculation, grain with F. culmorum mycelium and conidia were suspended in distilled water for $1 \mathrm{~h}$ and filtered through two layers of cheesecloth to obtain a conidial suspension without mycelium. Concentrations of the suspensions from all the isolates were adjusted to $5 \times 10^{5}$ spores $/ \mathrm{mL}$ with a hemocytometer. Equal volumes of conidial suspensions of three isolates were mixed.

\subsection{Field Experiments}

Resistance of 26 breeding lines and cultivar 'Tonacja' of winter wheat was evaluated. 'Tonacja' is one of the most frequently grown wheat cultivars in Poland and is medium-resistant to FHB. Wheat lines were sown in two field trials located in Radzików near Warsaw (GPS coordinates 52.212612, 20.633111) and in Cerekwica near Poznań (GPS coordinates 52.522579, 16.688624) in 2008. Field trials were arranged in a randomized complete block design. Wheat was sown at $1 \mathrm{~m}^{2}$ plots in four replicates. Three replicates were inoculated; the fourth replicate was left uninoculated and served as a check of natural infection. Fungicides were not applied to the experimental plots.

Wheat heads were inoculated at the anthesis stage with conidial suspension of F. culmorum. The inoculation rate was about $100 \mathrm{~mL}$ of suspension per plot $\left(1 \mathrm{~m}^{2}\right)$. Plots were inoculated separately at the beginning of anthesis $(61 \mathrm{BBCH})$, and inoculation was repeated about three days later at full anthesis (65 BBCH). Flowering time in Cerekwica, located in western Poland, was about one week earlier than in Radzików. Full anthesis stage was on average in Cerekwica, on June 1, and in Radzików, on June 8. In Radzików, plots were inoculated in the evening, when the relative air humidity increased. In Cerekwica, plots were mist-irrigated for 3 days after inoculation.

The mean percentage of blighted spikelets per infected head (FHB severity) and the percentage of infected heads per plot (FHB incidence) were scored. Disease severity was scored only on heads on a plot showing FHB symptoms. Fusarium head blight index (FHBi) was calculated from the FHB severity and FHB incidence using the following formula:

$$
\mathrm{FHB}_{\mathrm{i}}=\left(\mathrm{FHB}_{\text {incidence }} \times \mathrm{FHB}_{\text {severity }}\right) / 100
$$

Fusarium head blight was assessed about 21 days after the last inoculation. At harvest, 30 heads were collected manually from each plot and threshed with a laboratory thresher at low wind speed to prevent loss of low-weight infected kernels. The number of Fusarium damaged kernels (FDK) was visually evaluated by dividing the grain sample into two categories: Healthy kernels and infected 
kernels showing different levels of damage [29]. Next, whole grain samples were roughly milled with a laboratory grinder and stored at $-20^{\circ} \mathrm{C}$ until further analyses of DNA and mycotoxins.

\subsection{DNA Extraction}

Five grams of milled grain was ground powdered in liquid $\mathrm{N}_{2}$ with eight steel balls using a homogenizer Geno/Grinder 2000 (OPS Diagnostics, Bridgewater, NJ, USA). DNA was extracted from $100 \mathrm{mg}$ of grain powder using a slightly modified CTAB (cetyl trimethylammonium bromide) method (http://gmo-crl.jrc.it/summaries/NK603-WEB-Protocol\%20Validation.pdf) [42]. The DNA samples were finally purified with a DNeasy Plant Kit (QIAGEN, Stockach, Germany). The manufacturer's procedure was applied.

Fusarium culmorum isolate 9560 was used for standard curves [74]. The isolate was grown on Potato Dextrose Agar (PDA) medium covered with sterile polyethylene circles. PDA plates were incubated at $22{ }^{\circ} \mathrm{C}$ with a $12 \mathrm{~h}$ photoperiod for one week. Next, mycelium was scraped from the polyethylene surface with a spatula and ground. The same method as for grain was used for mycelium grinding and F. culmorum DNA extraction.

\subsection{Fusarium culmorum DNA Analysis}

The concentration of F. culmorum DNA in grain of wheat lines was analysed using quantitative real-time PCR according to the methodology developed by Nicolaisen et al. [42]. Two pairs of primers based on TEF- $1 \alpha$ genes were applied-primers specific for F. culmorum and for plant DNA (wheat). (Table 5).

Table 5. Sequences and names of F. culmorum and plant EF1 $\alpha$ gene specific primers [31].

\begin{tabular}{ccc}
\hline Target & Primer Name & Sequence $\left(5^{\prime}-\mathbf{3}^{\prime}\right)$ \\
\hline \multirow{2}{*}{ F. culmorum } & FculC561 fwd & CACCGTCATTGGTATGTTGTCACT \\
& FculC614 rev & CGGGAGCGTCTGATAGTCG \\
Plant TEF-1 $\alpha$ & Hor1f & TCTCTGGGTTTGAGGGTGAC \\
& Hor2r & GGCCCTTGTACCAGTCAAGGT \\
\hline
\end{tabular}

Quantitative real-time PCR was carried out using SYBR Green method described in detail by Nielsen et al. [48,74]. PCR was performed on a 7900HT Sequence Detection System (Applied Biosystems, Foster City, CA, USA).

Standard curves for the F. culmorum species and wheat were made of a fivefold dilution series using fungal DNA from pure cultures (described above) as well as wheat DNA. The amount of F. culmorum DNA was calculated from the cycle threshold $(C t)$ values using the standard curve.

As SYBR Green (DNA-binding fluorescent dye) binds to all double-stranded DNA and the results for each sample were evaluated by examining the dissociation curve and $\mathrm{Ct}$ value. The plant assay was used to calculate a relative measurement for Fusarium biomass in each sample, which was expressed as picograms of fungal DNA per micrograms of plant DNA according to Nicolaisen et al. [42] and Nielsen et al. [74].

\subsection{Analysis of Mycotoxins}

The analysis of mycotoxins was based on extraction with aqueous acetonitrile, purification with MultiSep ${ }^{\circledR} 227$ Trich+ columns (Romer Labs Inc., Union, MO, USA), and GC-ECD analysis method, according to Weingaertner et al. [75] with modifications.

Mycotoxins were extracted from $5 \mathrm{~g}$ of ground grains using $25 \mathrm{~mL}$ of an aqueous solution of acetonitrile (acetonitrile:water, 84:16, $v / v$ ). Samples were shaken on the laboratory shaker overnight, centrifuged ( $3000 \mathrm{rpm} / \mathrm{min}, 5 \mathrm{~min}$ ), and $6 \mathrm{~mL}$ of the extract was purified with MycoSep ${ }^{\circledR} 227$ Trich+ columns (Romer Labs Inc., Union, MO, USA). Internal standard solution ( $\alpha$-chloralose, $1 \mathrm{~mL}, 1 \mu \mathrm{g} / \mathrm{mL}$ in acetonitrile) was added to $4 \mathrm{ml}$ of purified extract and the solution was evaporated to dryness in the 
stream of air. Mycotoxins were derivatized to the trimethylsilyl derivatives with $75 \mu \mathrm{L}$ of derivatizing agent, Sylon BTZ (BSA + TMCS + TMSI, 3:2:3, Supelco), and heated $30 \mathrm{~min}$ in $60^{\circ} \mathrm{C}$. After dissolution of sample in $1 \mathrm{~mL}$ of isooctane, the excess of derivatizing agent was decomposed and removed with water. The organic layer was transferred to an autosampler vial and 1 microliter of solution was injected on GC.

Content of the trichothecenes of group B in the grain (DON, 3AcDON, 15AcDON, NIV) was analysed using the gas chromatography technique. Gas chromatograph SRI 8610C (SRI Instruments, Earl St. Torrance, CA, USA), equipped with a splitless injector, ${ }^{63} \mathrm{Ni}$ electron capture detector (ECD) (VICI Valco Instruments, Schenkon, Switzerland), HT300A autosampler (HTA S.R.L., Brescia, Italy), HG 2200 (CLAIND srl, Tremezzo, Italy) hydrogen generator, BGB-5MS $30 \mathrm{~m} \times 0.25 \mathrm{~mm} \times 0.25 \mu \mathrm{m}$ column (BGB Analytik Vertrieb GmbH, Rheinfelden, Germany) and PeakSimple data processing program were used.

The carrier gas was hydrogen, adjusted to pressure $12 \mathrm{psi}$, with nitrogen as a make-up gas at $60 \mathrm{~mL} / \mathrm{min}$. Elution was carried out in the temperature gradient: Initial temperature was $170{ }^{\circ} \mathrm{C}$, increased to $250{ }^{\circ} \mathrm{C}$ at $5{ }^{\circ} \mathrm{C} / \mathrm{min}$., and increased from $250{ }^{\circ} \mathrm{C}$ to $300{ }^{\circ} \mathrm{C}$ at $10^{\circ} \mathrm{C} / \mathrm{min}$., followed by a holding time of $5 \mathrm{~min}$., and decreased to $170{ }^{\circ} \mathrm{C}$. Individual compounds were identified by comparing the retention time of these with the retention times of the pure standards of mycotoxins (Biopure). The injection port and detector operated at $250{ }^{\circ} \mathrm{C}$ and $300{ }^{\circ} \mathrm{C}$, respectively. The concentration of mycotoxins was established based on the calibration curve, using $\alpha$-chloralose (Sigma-Aldrich sp. z o.o., Poznań, Poland) as the internal standard.

Preliminary studies on the analytical method (data not shown) revealed the repeatability (RSD) of the method, $7.2 \%$ for DON and $10.6 \%$ for NIV. Experiments on wheat meal spiked with pure mycotoxins $(1000 \mu \mathrm{g} / \mathrm{kg}$ of each) showed recovery of DON—93\% and NIV—-72\%. All results were corrected for recovery.

\subsection{Statistical Analysis}

Analysis of variance of the FHB index and FDK data (including Tukey's pairwise comparison at the level of significance $p=0.05$ ) was accomplished using the GLM (general linear model) procedure of SAS 9.2 package (SAS Institute Polska, Warszawa, Poland, 2008). Data were analysed separately for two locations and combined with location as the independent effect.

The relationships between the results for the FHB index, FDK, and Fusarium biomass and toxins were explored by Pearson correlation tests. Prior to analysis, all data were log transformed to stabilize variances. Wheat lines were grouped according to their resistance to FHB using the k-means clustering method. Groups of lines were created based on their resistance characterized by the FHB index, FDK, amounts of F. culmorum DNA, DON, and NIV. Trace (W) classification criterion was applied. This criterion is sensitive to effects of scale; thus, all variables were standardized prior to the analysis.

The correlation and k-means analysis were performed using Microsof $\mathrm{f}^{\circledR}$ Excel 2010/XLSTAT@-Pro (Version 2015.2.02.18135, Addinsoft, Inc., Brooklyn, NY, USA).

Author Contributions: The experiments were conceived and designed by T.G., H.W., and D.W.-G. The experiments were performed by T.G., H.W. and D.W-G. Molecular species identification and chemotype determination was performed by Ł.S. Toxins were analyzed by P.O. Real-time PCR analysis and interpretation of the results were conducted by T.G. and L.K.N. Data was statistically analyzed by T.G. The paper was written by T.G. and H.W. All authors read and approved the final manuscript.

Funding: This research was supported from the European Network for the Durable Exploitation of Crop Strategies 'ENDURE' project funded by the Sixth Framework Programme of the EU, number 031499 and from the grant number HOR hn-4040 dec-7 / 08 funded by Ministry of Agriculture and Rural Development of Poland.

Acknowledgments: Authors wish to thank wheat breeders from Polish companies Plant Breeding Strzelce, DANKO Plant Breeders, Poznan Plant Breeding, Plant Breeding Smolice and Małopolska Plant Breeding for providing wheat lines for the experiment. First author appreciate the expert assistance provided by Lise Nistrup Jørgensen and Annemarie Fejer Justesen from Department of Agroecology, Århus University, Denmark. 
Conflicts of Interest: The authors declare no conflict of interest. The founding sponsors had no role in the design of the study; in the collection, analyses, or interpretation of data; in the writing of the manuscript, and in the decision to publish the results.

\section{References}

1. Snijders, C.H.A. Resistance in wheat to Fusarium infection and trichothecene formation. Toxicol. Lett. 2004, 153, 37-46. [CrossRef] [PubMed]

2. Bottalico, A.; Perrone, G. Toxigenic Fusarium species and mycotoxins associated with head blight in small-grain cereals in Europe. Eur. J. Plant Pathol. 2002, 108, 611-624. [CrossRef]

3. Mesterházy, Á.; Bartók, T.; Mirocha, C.G.; Komoróczy, R. Nature of wheat resistance to Fusarium head blight and the role of deoxynivalenol for breeding. Plant Breed. 1999, 118, 97-110. [CrossRef]

4. Foroud, N.A.; Eudes, F. Trichothecenes in cereal grains. Int. J. Mol. Sci. 2009, 10, 147-173. [CrossRef] [PubMed]

5. Schroeder, H.W.; Christensen, J.J. Factors affecting resistance of wheat to scab caused by Gibberella zeae. Phytopathology 1963, 53, 831-838.

6. Mesterházy, Á. Types and components of resistance to Fusarium head blight of wheat. Plant Breed. 1995, 114, 377-386. [CrossRef]

7. Kluger, B.; Bueschl, C.; Lemmens, M.; Michlmayr, H.; Malachova, A.; Koutnik, A.; Maloku, I.; Berthiller, F.; Adam, G.; Krska, R.; et al. Biotransformation of the mycotoxin deoxynivalenol in Fusarium resistant and susceptible near isogenic wheat lines. PLoS ONE 2015, 10, e0119656. [CrossRef]

8. Boutigny, A.-L.; Richard-Forget, F.; Barreau, C. Natural mechanisms for cereal resistance to the accumulation of Fusarium trichothecenes. Eur. J. Plant Pathol. 2008, 121, 411-423. [CrossRef]

9. Argyris, J.; Van Sanford, D.; TeKrony, D. Fusarium graminearum infection during wheat seed development and its effect on seed quality. Crop Sci. 2003, 43, 1782-1788. [CrossRef]

10. Horevaj, P.; Gale, L.; Milus, E. Resistance in winter wheat lines to initial infection and spread within spikes by deoxynivalenol and nivalenol chemotypes of Fusarium graminearum. Plant Dis. 2011, 95, 31-37. [CrossRef]

11. Kubo, K.; Kawada, N.; Fujita, M.; Hatta, K.; Oda, S.; Nakajima, T. Effect of cleistogamy on Fusarium head blight resistance in wheat. Breed. Sci. 2010, 60, 405-411. [CrossRef]

12. Skinnes, H.; Semagn, K.; Tarkegne, Y.; Marøy, A.G.; Bjørnstad, Å. The inheritance of anther extrusion in hexaploid wheat and its relationship to Fusarium head blight resistance and deoxynivalenol content. Plant Breed. 2010, 129, 149-155. [CrossRef]

13. Lu, Q.; Lillemo, M.; Skinnes, H.; He, X.; Shi, J.; Ji, F.; Dong, Y.; Bjørnstad, A. Anther extrusion and plant height are associated with Type I resistance to Fusarium head blight in bread wheat line "Shanghai-3/Catbird". Theor. Appl. Genet. 2013, 126, 317-334. [CrossRef] [PubMed]

14. Kociuba, W.; Kramek, A. The analysis of some characteristics of triticale flowering biology suitable for breeding and reproduction of cultivars. Ann. UMCS 2004, 59, 115-122. (In Polish)

15. Kubo, K.; Fujita, M.; Kawada, N.; Nakajima, T.; Nakamura, K.; Maejima, H.; Ushiyama, T.; Hatta, K.; Matsunaka, H. Minor differences in anther extrusion affect resistance to Fusarium head blight in wheat. J. Phytopathol. 2013, 161, 308-314. [CrossRef]

16. Miller, S.S.; Chabot, D.M.P.; Ouellet, T.; Harris, L.J.; Fedak, G. Use of a Fusarium graminearum strain transformed with green fluorescent protein to study infection in wheat (Triticum aestivum). Can. J. Plant Pathol. 2004, 26, 453-463. [CrossRef]

17. Strange, R.N.; Smith, H. A fungal growth stimulant in anthers, which predisposes wheat to attack by Fusarium graminearum. Physiol. Plant Pathol. 1971, 1, 141-150. [CrossRef]

18. Strange, R.N.; Majer, J.R.; Smith, H. The isolation and identification of choline and betaine as the two major components in anthers and wheat germ that stimulate Fusarium graminearum in vitro. Physiol. Plant Pathol. 1974, 4, 277-290. [CrossRef]

19. Pearce, R.B.; Strange, R.N.; Smith, H. Glycinebetaine and choline in wheat: Distribution and relation to infection by Fusarium graminearum. Phytochemistry 1976, 15, 953-954. [CrossRef]

20. Kang, Z.; Buchenauer, H. Cytology and ultrastructure of the infection of wheat spikes by Fusarium culmorum. Mycol. Res. 2000, 104, 1083-1093. [CrossRef] 
21. Rudd, J.C.; Horsley, R.D.; McKendry, A.L.; Elias, E.M. Host plant resistance genes for Fusarium head blight. Crop Sci. 2001, 41, 620. [CrossRef]

22. Gosman, N.; Steed, A.; Chandler, E.; Thomsett, M.; Nicholson, P. Evaluation of type I Fusarium head blight resistance of wheat using non-deoxynivalenol-producing fungi. Plant Pathol. 2010, 59, 147-157. [CrossRef]

23. Buerstmayr, H.; Buerstmayr, M.; Schweiger, W.; Steiner, B. Breeding for resistance to head blight caused by Fusarium spp. in wheat. CAB Rev. Perspect. Agric. Vet. Sci. Nutr. Nat. Resour. 2014, 9, 236-276. [CrossRef]

24. Bai, G.H.; Shaner, G.; Ohm, H. Inheritance of resistance to Fusarium graminearum in wheat. Theor. Appl. Genet. 2000, 100, 1-8. [CrossRef]

25. Buerstmayr, H.; Lemmens, M.; Hartl, L.; Doldi, L.; Steiner, B.; Stierschneider, M.; Ruckenbauer, P. Molecular mapping of QTLs for Fusarium head blight resistance in spring wheat. I. Resistance to fungal spread (type II resistance). Theor. Appl. Genet. 2002, 104, 84-91. [CrossRef] [PubMed]

26. Buerstmayr, H.; Ban, T.; Anderson, J.A. QTL mapping and marker-assisted selection for Fusarium head blight resistance in wheat: A review. Plant Breed. 2009, 128, 1-26. [CrossRef]

27. Jin, Y.; Zhang, X.; Rudd, R.; Rudd, J. A point inoculation method for evaluating scab resistance in wheat. In 1999 National Fusarium Head Blight Forum; Wagester, J.A., Ward, R., Hart, L.P., Hazen, S.P., Lewis, J., Borden, H., Eds.; Michigan State University: East Lansing, MI, USA, 1999; p. 128.

28. Bai, G.H.; Plattner, R.; Desjardins, A.; Kolb, F. Resistance to Fusarium head blight and deoxynivalenol accumulation in wheat. Plant Breed. 2001, 120,1-6. [CrossRef]

29. Argyris, J.; TeKrony, D.; Hershman, D.; VanSanford, D.; Hall, M.; Kennedy, B.; Rucker, M.; Edge, C. Fusarium head blight infection following point inoculation in the greenhouse compared with movement of Fusarium graminearum in seed and floral components. Crop Sci. 2005, 45, 626-634. [CrossRef]

30. Miedaner, T.; Moldovan, M.; Ittu, M. Comparison of spray and point inoculation to assess resistance to Fusarium head blight in a multienvironment wheat trial. Phytopathology 2003, 93, 1068-1072. [CrossRef]

31. Van Ginkel, M.; Gilchrist, L. How to make intelligent crosses to accumulate Fusarium head blight resistance genes based on knowledge of the underlying resistance mechanisms. In 2002 National Fusarium Head Blight Forum Proceedings; Canty, S., Lewis, J., Siler, L., Ward, R.W., Eds.; Michigan State University: East Lansing, MI, USA, 2002; pp. 268-272.

32. Bai, G.; Kolb, F.L.; Shaner, G.; Domier, L.L. Amplified fragment length polymorphism markers linked to a major quantitative trait locus controlling scab resistance in wheat. Phytopathology 1999, 89, 343-348. [CrossRef]

33. Zwart, R.S.; Muylle, H.; Van Bockstaele, E.; Roldán-Ruiz, I. Evaluation of genetic diversity of Fusarium head blight resistance in European winter wheat. Theor. Appl. Genet. 2008, 117, 813. [CrossRef] [PubMed]

34. Lemmens, M.; Buerstmayr, H.; Krska, R.; Schuhmacher, R.; Grausgruber, H.; Ruckenbauer, P. The effect of inoculation treatment and long-term application of moisture on Fusarium head blight symptoms and deoxynivalenol contamination in wheat grains. Eur. J. Plant Pathol. 2004, 110, 299-308. [CrossRef]

35. Perkowski, J.; Buśko, M.; Stuper, K.; Kostecki, M.; Matysiak, A.; Szwajkowska-Michałek, L. Concentration of ergosterol in small-grained naturally contaminated and inoculated cereals. Biologia 2008, 63, 542-547. [CrossRef]

36. Doohan, F.M.; Parry, D.W.; Nicholson, P. Fusarium ear blight of wheat: The use of quantitative PCR and visual disease assessment in studies of disease control. Plant Pathol. 1999, 48, 209-217. [CrossRef]

37. Schnerr, H.; Vogel, R.F.; Niessen, L. Correlation between DNA of trichothecene-producing Fusarium species and deoxynivalenol concentrations in wheat-samples. Lett. Appl. Microbiol. 2002, 35, 121-125. [CrossRef] [PubMed]

38. Xu, X.; Parry, D.W.; Nicholson, P.; Thomsett, M.A.; Simpson, D.; Edwards, S.G.; Cooke, B.M.; Doohan, F.M.; Van Maanen, A.; Moretti, A.; et al. Is the amount of mycotoxins in cereal grains related to the quantity of Fusarium DNA? Asp. Appl. Biol. 2003, 68, 101-108.

39. Opoku, N.; Back, M.A.; Edwards, S.G. Susceptibility of cereal species to Fusarium langsethiae under identical field conditions. Eur. J. Plant Pathol. 2018, 150, 869-879. [CrossRef]

40. Leišová, L.; Kučera, L.; Chrpová, J.; Sýkorová, S.; Šíp, V.; Ovesná, J. Quantification of Fusarium culmorum in wheat and barley tissues using real-time PCR in comparison with DON content. J. Phytopathol. 2006, 154, 603-611. [CrossRef] 
41. Waalwijk, C.; Van Der Heide, R.; De Vries, I.; Van Der Lee, T.; Schoen, C.; Costrel-de Corainville, G.; Häuser-Hahn, I.; Kastelein, P.; Köhl, J.; Lonnet, P.; et al. Quantitative detection of Fusarium species in wheat using TaqMan. Eur. J. Plant Pathol. 2004, 110, 481-494. [CrossRef]

42. Nicolaisen, M.; Suproniene, S.; Nielsen, L.K.; Lazzaro, I.; Spliid, N.H.; Justesen, A.F. Real-time PCR for quantification of eleven individual Fusarium species in cereals. J. Microbiol. Methods 2009, 76, 234-240. [CrossRef]

43. Reischer, G.H.; Lemmens, M.; Farnleitner, A.; Adler, A.; Mach, R.L. Quantification of Fusarium graminearum in infected wheat by species specific real-time PCR applying a TaqMan probe. J. Microbiol. Methods 2004, 59, 141-146. [CrossRef] [PubMed]

44. Stanisz, E.; Zgoła-Grześkowiak, A.; Waśkiewicz, A.; Stępień, Ł.; Beszterda, M. Can ergosterol be an indicator of Fusarium fungi and mycotoxins in cereal products? J. Braz. Chem. Soc. 2015, 15, 18-23.

45. Berthiller, F.; Crews, C.; Dall'Asta, C.; Saeger, S.D.; Haesaert, G.; Karlovsky, P.; Oswald, I.P.; Seefelder, W.; Speijers, G.; Stroka, J. Masked mycotoxins: A review. Mol. Nutr. Food Res. 2013, 57, 165-186. [CrossRef] [PubMed]

46. Boutigny, A.-L.; Atanasova-Pénichon, V.; Benet, M.; Barreau, C.; Richard-Forget, F. Natural phenolic acids from wheat bran inhibit Fusarium culmorum trichothecene biosynthesis in vitro by repressing Tri gene expression. Eur. J. Plant Pathol. 2010, 127, 275-286. [CrossRef]

47. Von der Ohe, C.; Miedaner, T. Competitive aggressiveness in binary mixtures of Fusarium graminearum and $F$. culmorum isolates inoculated on spring wheat with highly effective resistance QTL. J. Phytopathol. 2010, 410. [CrossRef]

48. Nielsen, L.K.; Jensen, J.D.; Rodríguez, A.; Jørgensen, L.N.; Justesen, A.F. TRI12 based quantitative real-time PCR assays reveal the distribution of trichothecene genotypes of F. graminearum and F. culmorum isolates in Danish small grain cereals. Int. J. Food Microbiol. 2012, 157, 384-392. [CrossRef] [PubMed]

49. Liu, Y.Y.; Sun, H.Y.; Li, W.; Xia, Y.L.; Deng, Y.Y.; Zhang, A.X.; Chen, H.G. Fitness of three chemotypes of Fusarium graminearum species complex in major winter wheat-producing areas of China. PLoS ONE 2017, 12. [CrossRef] [PubMed]

50. Goswami, R.S.; Kistler, H.C. Pathogenicity and in planta mycotoxin accumulation among members of the Fusarium graminearum species complex on wheat and rice. Phytopathology 2005, 95, 1397-1404. [CrossRef]

51. Lemmens, M.; Koutnik, A.; Steiner, B.; Buerstmayr, H.; Berthiller, F.; Schuhmacher, R.; Maier, F.; Schäfer, W. Investigations on the ability of $F h b 1$ to protect wheat against nivalenol and deoxynivalenol. Cereal Res. Commun. 2008, 36, 429-435. [CrossRef]

52. Eudes, F.; Comeau, A.; Collin, S.R. Phytotoxicité de huit mycotoxines associées à la fusariose de l'épi chez le blé. Can. J. Plant Pathol. 2000, 22, 286-292. [CrossRef]

53. Foroud, N.A.; McCormick, S.P.; MacMillan, T.; Badea, A.; Kendra, D.F.; Ellis, B.E.; Eudes, F. Greenhouse studies reveal increased aggressiveness of emergent Canadian Fusarium graminearum chemotypes in wheat. Plant Dis. 2012, 96, 1271-1279. [CrossRef]

54. Escrivá, L.; Font, G.; Manyes, L. In vivo toxicity studies of Fusarium mycotoxins in the last decade: A review. Food Chem. Toxicol. 2015. [CrossRef]

55. Alassane-Kpembi, I.; Puel, O.; Pinton, P.; Cossalter, A.M.; Chou, T.C.; Oswald, I.P. Co-exposure to low doses of the food contaminants deoxynivalenol and nivalenol has a synergistic inflammatory effect on intestinal explants. Arch. Toxicol. 2017, 91, 2677-2687. [CrossRef] [PubMed]

56. Brunner, K.; Kovalsky Paris, M.P.; Paolino, G.; Bürstmayr, H.; Lemmens, M.; Berthiller, F.; Schuhmacher, R.; Krska, R.; MacH, R.L. A reference-gene-based quantitative PCR method as a tool to determine Fusarium resistance in wheat. Anal. Bioanal. Chem. 2009, 395, 1385-1394. [CrossRef] [PubMed]

57. Horevaj, P.; Milus, E.A.; Bluhm, B.H. A real-time qPCR assay to quantify Fusarium graminearum biomass in wheat kernels. J. Appl. Microbiol. 2011, 111, 396-406. [CrossRef] [PubMed]

58. Scheider, N.; Guo, J.R.; Verreet, J.A.; Beyer, M. Assessing the intensity of Fusarium-damage in wheat: A comparison of selected disease parameters during disease development and the role of fungicides. J. Plant Dis. Prot. 2009, 116, 118-123. [CrossRef]

59. Schlang, N.; Duveiller, E. Current approaches and utilization of new screening techniques for evaluation of FHB resistance at CIMMYT. Plant Breed. Seed Sci. 2011, 64. [CrossRef] 
60. Rossi, V.; Terzi, V.; Moggi, F.; Morcia, C.; Faccioli, P.; Haidukowski, M.; Pascale, M. Assessment of Fusarium infection in wheat heads using a quantitative polymerase chain reaction (qPCR) assay. Food Addit. Contam. 2007, 24, 1121-1130. [CrossRef]

61. Mesterházy, Á.; Tóth, B.; Bartók, T.; Varga, M. Breeding strategies against FHB in winter wheat and their relation to type I resistance. Cereal Res. Commun. 2008, 36, 37-43. [CrossRef]

62. Mesterházy, Á. Role of deoxynivalenol in aggressiveness of Fusarium graminearum and F. culmorum and in resistance to Fusarium head blight. Eur. J. Plant Pathol. 2002, 108, 675-684. [CrossRef]

63. Miedaner, T.; Heinrich, N.; Schneider, B.; Oettler, G.; Rohde, S.; Rabenstein, F. Estimation of deoxynivalenol (DON) content by symptom rating and exoantigen content for resistance selection in wheat and triticale. Euphytica 2004, 139, 123-132. [CrossRef]

64. Góral, T.; Wiśniewska, H.; Ochodzki, P.; Walentyn-Góral, D. Higher Fusarium toxin accumulation in grain of winter triticale lines inoculated with Fusarium culmorum as compared with wheat. Toxins 2016, 8, 301. [CrossRef] [PubMed]

65. Miedaner, T.; Schneider, B.; Oettler, G. Means and variances for Fusarium head blight resistance of $\mathrm{F}_{2}$-derived bulks from winter triticale and winter wheat crosses. Euphytica 2006, 152, 405-411. [CrossRef]

66. Oettler, G.; Heinrich, N.; Miedaner, T. Estimates of additive and dominance effects for Fusarium head blight resistance of winter triticale. Plant Breed. 2004, 123, 525-530. [CrossRef]

67. Oettler, G.; Wahle, G. Genotypic and environmental variation of resistance to head blight in triticale inoculated with Fusarium culmorum. Plant Breed. 2001, 120, 297-300. [CrossRef]

68. Ochodzki, P.; Góral, T. Production of mycotoxins by selected Fusarium graminearum and F. culmorum isolates cultured on rice and wheat. In Proceedings of the Conference on 28 Mykotoxin-Workshop, Bydgoszcz, Poland, 29-31 May 2006; p. 73.

69. Wiśniewska, H.; Kowalczyk, K. Resistance of cultivars and breeding lines of spring wheat to Fusarium culmorum and powdery mildew. J. Appl. Genet. 2005, 46, 35-40. [PubMed]

70. Snijders, C.H.A.; Perkowski, J. Effects of head blight caused by Fusarium culmorum on toxin content and weight of wheat kernels. Phytopathology 1990, 80, 566-570. [CrossRef]

71. Chełkowski, J.; Gromadzka, K.; Stępień, Ł.; Lenc, L.; Kostecki, M.; Berthiller, F. Fusarium species, zearalenone and deoxynivalenol content in preharvest scabby wheat heads from Poland. World Mycotoxin J. 2012, 5, 133-141. [CrossRef]

72. Wiśniewska, H.; Stępień, Ł.; Waśkiewicz, A.; Beszterda, M.; Góral, T.; Belter, J. Toxigenic Fusarium species infecting wheat heads in Poland. Open Life Sci. 2014, 9, 163-172. [CrossRef]

73. Stepień, L.; Gromadzka, K.; Chelkowski, J. Polymorphism of mycotoxin biosynthetic genes among Fusarium equiseti isolates from Italy and Poland. J. Appl. Genet. 2012, 53, 227-236. [CrossRef] [PubMed]

74. Nielsen, L.K.; Jensen, J.D.; Nielsen, G.C.; Jensen, J.E.; Spliid, N.H.; Thomsen, I.K.; Justesen, A.F.; Collinge, D.B.; Jørgensen, L.N. Fusarium head blight of cereals in Denmark: Species complex and related mycotoxins. Phytopathology 2011, 101, 960-969. [CrossRef] [PubMed]

75. Weingaertner, J.; Krska, R.; Praznik, W.; Grasserbauer, M.; Lew, H. Use of Mycosep multifunctional clean-up columns for the determination of trichothecenes in wheat by electron-capture gas chromatography. Fresenius J. Anal. Chem. 1997, 357, 1206-1210. [CrossRef]

(c) 2018 by the authors. Licensee MDPI, Basel, Switzerland. This article is an open access article distributed under the terms and conditions of the Creative Commons Attribution (CC BY) license (http://creativecommons.org/licenses/by/4.0/). 